\title{
INFLUÊNCIA DO HORÁRIO DE COLETA E ESTÁDIO DE DESENVOLVIMENTO FLORAL SOBRE A VIABILIDADE POLÍNICA EM \\ Physalis ixocarpa
}

\author{
$\underline{\text { Alismário Leite da Silva }}{ }^{1}$; Adriana Rodrigues Passos ${ }^{2}$; Keylla Souza dos Santos ${ }^{3}$ \\ 1. Bolsista PROBIC/UEFS, Graduando em Agronomia, Universidade Estadual de Feira de Santana, e-mail: \\ alismarioagronomo@hotmail.com \\ 2. Orientadora, Departamento de Biologia, Universidade Estadual de Feira de Santana, e-mail: \\ adrianarpassos@yahoo.com.br \\ 3. Doutoranda em Recursos Genéticos Vegetais, Universidade Estadual de Feira de Santana, e-mail: \\ keyllasouzas@yahoo.com.br
}

PALAVRAS-CHAVE: Grãos de pólen; Viabilidade; Lactofenol-azul de anilina.

\section{INTRODUÇÃO}

A Physalis ixocarpa Brot, conhecida popularmente como tomatilho, é uma planta herbácea pertencente a família Solanaceae. Constitui uma hortaliça que tem sido cultivada no México e na América Central desde os tempos pré-colombianos. Seus frutos, denominados no México como tomate 'tomate verde' ou 'de shell '(tomate casca), são utilizados para a preparação de saborosos molhos. No México, esta cultura ocupa cerca de 15 mil ha, com rendimentos 160.000 toneladas por ano (SARH/DGEA, 1984).

Como descrito para o gênero Physalis, a espécie $P$. ixocarpa apresenta propriedades medicinais. Estudos realizados por Drost Karbowska et al (1993) e Tomassini et al (2000) relatam a presença de alcalóides quaternários, vitaesteróides (fisalinas, ixocarpalactona A), flavonóides e saponinas.

Entretanto, estudos destinados ao conhecimento amplo da espécie são ainda limitados, e para desenvolvimento de um programa de melhoramento, faz-se necessário a realização de análises que possibilitem a produção de sementes viáveis, resultando em formação de plantas com elevados níveis de produtividades. O conhecimento da viabilidade polínica é de extrema importância, para que se possam obter resultados positivos em cruzamentos dirigidos, resultando na formação de gametas normais e balanceados. A elevada instabilidade meiótica, associada às anormalidades genéticas e/ou aberrações cromossômicas, podem resultar na formação de plantas atípicas, machoestéreis ou incapazes de formar grãos de pólen, o que pode prejudicar a produção de sementes, assim como afetar a polinização (POZZOBON et al, 2011). Estes estudos além de evidenciar a potencialidade reprodutora masculina da espécie, contribui em estudos taxonômicos, ecológicos, palinológicos, fornecendo informações básicas para a aplicação prática na conservação genética, bem como na agricultura, para o planejamento de algum tipo de melhoramento ou cultivo (ALEXANDER, 1980; ARROYO, 1981; GUINET 1989).

Segundo Souza et al. (2002), a viabilidade e a germinabilidade polínica constituem-se fatores importantes para o o sucesso no melhoramento da espécie, levando-se em consideração que cada grão de pólen leva consigo os materiais genéticos resultantes da recombinação, fazendo com que estas plantas transmitam à próxima geração genótipos amplamente diversificados, tamanha a probabilidade de diferentes combinações entre os alelos que ocorrem na meiose.

Sendo assim, o presente trabalho teve como objetivo avaliar a taxa de fertilidade da planta ao longo do dia, e em diferentes fases de desenvolvimento do botão floral, a fim de determinar o horário e estádio com maior disponibilidade dos grãos de pólen viáveis em Physalis ixocarpa. 


\section{MATERIAL E MÉTODOS}

Foram utilizadas plantas de Physalis ixocarpa, procedendo a realização do teste de viabilidade de pólen por meio do método de coloração com Lactofenol-azul de anilina, onde botões florais em pré antese e flores abertas foram coletadas no período de 8:00, 11:00, 14:00 e 17:00 horas. As anteras foram dispostas em lâminas contendo Lactofenol-azul de anilina, onde foram efetuados cortes para liberação dos grãos de pólen. Posteriormente, o material foi coberto com lamínula e observado em microscópio (colocar as especificações do microscópio).

Foram confeccionadas 7 lâminas das quais contabilizou-se 200 grãos de pólen por lâmina. A viabilidade do pólen foi determinada de acordo com o nível de coloração: pólen corado de azul como viável e incolor como não viáveis.

Os dados obtidos foram submetidos a análise de variância e teste de média por meio do teste de tukey a $1 \%$ de probabilidade, e por análise de regressão, utilizando o software estatístico SISVAR (FERREIRA, 2003). A porcentagem de grãos de pólen viáveis foi determinada de acordo com a fórmula:

Viabilidade do pólen $(\%)=\underline{\mathrm{N}^{\circ} \text { de grãos de pólen corados x } 100}$

$$
\mathrm{N}^{\circ} \text { de grãos pólen total }
$$

\section{RESULTADOS E/OU DISCUSSÃO}

A análise de variância mostrou diferenças significativas a $1 \%$ de probabilidade para o fator estádio, horário e a interação entre o estádio e o horário, para as avaliações de viabilidade de pólen em estádio de botão em pré-antese e após a antese para diferentes horários de observação (Tabela 1).

Tabela 1. Resumo da análise de variância para os fatores de variação estádio, horário e interação estádio horário.

\begin{tabular}{lccccc}
\hline FV & GL & SQ & QM & Fc Pr>Fc \\
\hline ESTADIO & 1 & 4095.125000 & 4095.125000 & 21.8020 .0001 \\
HORARIO & 3 & 7740.000000 & 2580.000000 & 13.7360 .0000 \\
ESTADIO*HORARIO & & 3 & 11050.375000 & 3683.458333 & 19.6100 .0000 \\
Erro & & 24 & 4508.000000 & 187.833333 & \\
\hline Total corrigido & 31 & 27393.500000 & & & \\
\hline \multicolumn{7}{l}{} \\
\hline CV $(\%)=$ & 17.10 & & & & \\
Média geral: & 80.1250000 & Número de observações: & 32 & \\
\hline
\end{tabular}

Significativo a $1 \%$ de probabilidade pelo teste $\mathrm{t}$.

Observou-se diferenças na viabilidade polínica apenas no horário de 11:00h, onde a flor aberta apresentou maior viabilidade de pólen em relação ao botão em préantese. Para os demais horários não foram encontradas diferenças na viabilidade para os diferentes estádios avaliados (Tabela 2). Observou-se menor viabilidade no estádio de pré-antese para o horário de 11:00 h. As avaliações com a flor aberta apresentaram uma maior viabilidade para todos os horários analisados quando comparando com o estádio de pré-antese, não diferindo entre os horários para o mesmo tratamento (Tabela 2). Fatores bióticos e abióticos podem ter sido responsáveis por essa variação na taxa de viabilidade polínica, porém não foram suficientes para comprometer a fertilidade da espécie para os dois estádios avaliados nos diferentes horários, exceto o botão em préantese as $11 \mathrm{~h}$, já os demais valores são considerados satisfatórios, pois corroboram com 
SOUZA et al. (2002), que consideram uma viabilidade polínica alta acima de $70 \%$ (Figura 1).

Tabela 2. Médias dos estádios florais para viabilidade polínica de Physalis ixocarpa observados em diferentes horários.

\begin{tabular}{ccccc}
\hline & \multicolumn{5}{c}{ VIABILIDADE POLÍNICA } \\
\hline TRATAMENTOS & $\mathbf{8 h}$ & $\mathbf{1 1 h}$ & $\mathbf{1 4 h}$ & $\mathbf{1 7 h}$ \\
\hline Botões Florais & $93,25 \mathrm{a}$ & $11,25 \mathrm{~b}$ & $83,00 \mathrm{a}$ & $78,50 \mathrm{a}$ \\
Flores & $96,00 \mathrm{a}$ & $97,00 \mathrm{a}$ & $94,25 \mathrm{a}$ & $87,75 \mathrm{a}$ \\
\hline
\end{tabular}

Estudos realizados por COSTA et al. (2012), onde foram avaliados os efeitos do horário de coleta de grãos de pólen em quatro variedades de milho (Zea mays) (AG1051, CO-9621, C-444 e Zapalote Chico), resultou na redução da viabilidade polínica a medida em que os horários de coleta foram avançando.

Souza et al. (2002) também constatou, em maracujá-amarelo, uma redução da viabilidade dos grãos de pólen com o progresso do tempo, resultando em diminuição da taxa de fertilidade da planta. Desta forma, é de fundamental importância estabelecer o melhor horário para coleta dos grãos de pólen, para garantir a fertilidade da planta receptora e formação do tubo polínico. Sendo assim, estudos que determinem o melhor estádio floral e o melhor horário de coleta são de extrema importância em trabalhos de melhoramento genético que visem hibridação, a fim de realizar cruzamentos com maior eficiência.

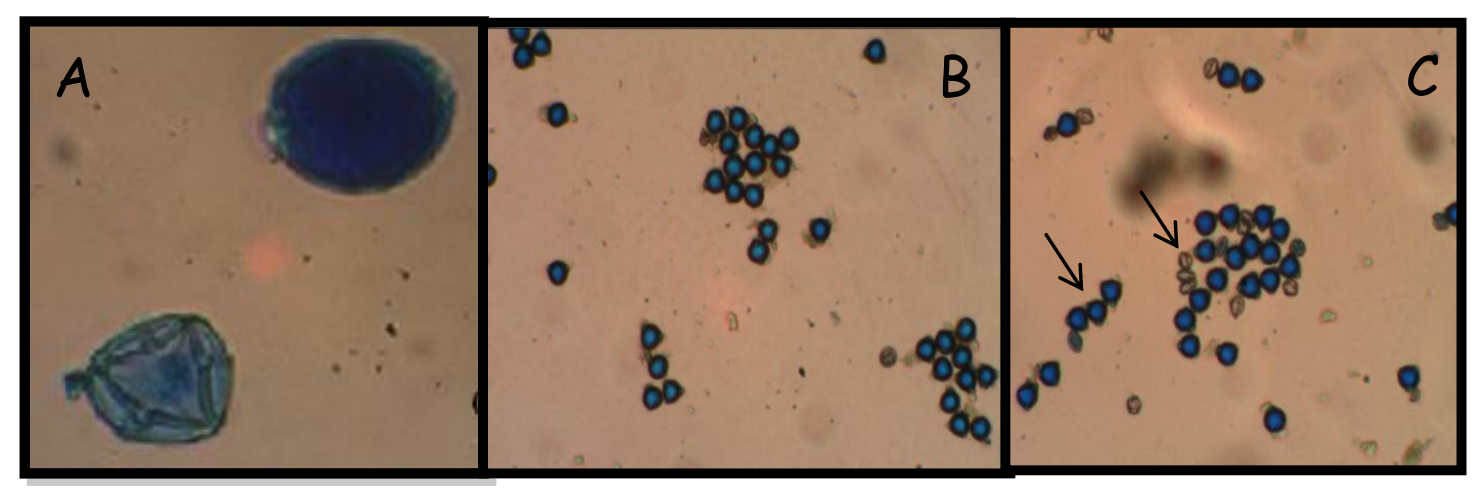

Figura 1. Grãos de pólen de Physalis ixocarpa corados com Lactofenol-azul de anilina. A) Grão de pólen viável e inviável. B) Grãos de pólen viáveis. C) Grãos de pólen viáveis e inviáveis (seta).

\section{CONSIDERAÇÕES FINAIS}

- O melhor horário para coleta dos grãos de pólen de Physalis ixocarpa para botões é de $8 \mathrm{~h}$ e para flores abertas é às $11 \mathrm{~h}$;

- As flores abertas apresentam maior viabilidade polínica;

- A espécie possui potencial para a produção de frutos viáveis.

\section{REFERÊNCIAS}


ALEXANDER, M.P. A. Versatile stain for pollen fungi, yeast and bacterium. Stain Tecnology, v.1, n.5, p.13-8, 1980.

COSTA, A.; ROMANI, I.; MAGALHÃES, V. J.; BERTI, F.L.; MARTINS, J. W.; GONELA, A. Efeito do horário de coleta sobre a viabilidade do pólen de Milho (Zeamays L.). XXIX CONGRESSO NACIONAL DE MILHO E SORGO. ÁGUAS DE LINDÓIA. Revista Brasileira de Milho e Sorgo. 2012.

DROST-KARBOWSKA, K., et al. Phytochemical investigation of the tomatillo fruit (Physalis ixocarpa Brot. Solanaceae). Acta Societatis Botanicorum Poloniae, v. 62 (3-4), p. 155-159, 1993.

FERREIRA, D. F. Programa de análises estatísticas (statistical analysis sotware) e planejamento de experimentos - SISVAR 5.0 (Build 67). Lavras: DEX/UFLA, 2003.

GUINET, P.H. Advances in legume biology: struture evolution, and biology of pollen in Leguminosae. St. Louis: Missouri Botanical Garden, 842p. 1989.

POZZOBON, M. T.; SOUZA, K. R. R.; CARVALHO, S. I. C.; REIFSCHNEIDER, F. J. B. Meiose e viabilidade polínica em linhagens avançadas de pimenta. Horticultura brasileira, v. 29, n. 2, abr.- junho, 2011.

SARH/DGEA (Secretaria de Agricultura y Recursos Hidráiulicos/Direccion General de Estadistica Agricola) (1984) Agenda de Informaci6n Estadistica Agropecuaria y, Forestal, M6xico. In: Malagón, R. R.; Ochoa-Alejo, N. O. Adventitious shoot formation and plant regeneration from tissues of tomatillo (Physalis ixocarpa Brot.). Plant Cell, Tissue and Organ Culture, V. 25, p. 185-188, 1991.

SOUZA. M.M.; Pereira TNS e Martins ER (2002) Microsporogênese associadas ao tamanho do botão floral e da antera e viabilidade polínica em maracujá-amarelo (Passiflora edulis Sims f. flavicarpa Degener). Ciência e Agrotecnologia 26: 1209-1217.

TOMASSINI, T. C. B.; BARBI, N.; RIBEIRO, I. M.; XAVIER, D. C. D. Gênero Physalis- uma revisão sobre vitaesteróides. Química Nova, V. 12, p. 47-57, 2000 . 